УДК 821.161,2-Франко:[398 111,84/0,85]

Вертій O. I. доктор філологічних наук, провідний науковий співробітник Інституту франкознавства, Львівський національний університет імені Івана Франка

\title{
ПИТАННЯ ЕСТЕТИКИ ТА ПОЕТИКИ УСНОЇ НАРОДНОЇ ТВОРЧОСТІ У ФОЛЬКЛОРИСТИЧНІЙ СПАДЩИНІ ІВАНА ФРАНКА
}

У статті йдеться про наукове потрактування І.Франком естетичних особливостей прадавнього (доміфологічного), нового (міфологічного) та новітнього (післяміфологічного) етапів становлення народного світогляду та поетикальних утворень різних фольклорних жанрів, а також значення ідей та висновків І.Франка для формування національних основоположних підстав сучасного украӥнського народознавства.

Ключові слова: естетика, фетишизм, анімізм, міф, новий світогляд.

В статье анализируется научная трактовка И.Франко эстетических особенностей древнего (домифологического), нового (мифологического) и новейшего (послемифологического) этапов становления народного мировоззрения и поэтикальных образований разных фольклорных жанров. Отмечается значение идей и выводов И.Франко для формирования методологии современного украинского народоведения.

Ключевые слова: эстетика, фетишизм, анимизм, миф, новое мировоззрение.

In the article is probed scientific understanding of I.Franko aesthetically features ancient time (beforemyfological), new time (mythological), newest time (af- 
termyfological) the stages of development of the folk thinking and forming on this basis of poetic texts of different folk-lore genres and also value of ideas and conclusions of I.Franko for forming of national bases of the modern Ukrainian ethnology.

Keywords: aesthetics, fetishism, animism, myth, new world view.

Постановка проблеми. Предметом пильної уваги І.Франка як народознавця була еволюція народнопоетичних уявлень про людину і світ та формування і становлення на цих підставах поетикальних утворень різних жанрів усної народної творчості. Цій проблемі присвячені його розвідки «Останки первісного світогляду в руських і польських загадках народних», «Як виникають народні пісні», «Як творилася слов’янська міфологія», «Студії над українськими народними піснями», «Українці», «Сербські народні думи і пісні», «Жіноча неволя в руських піснях народних», «Національний колорит у казках Бодянського», «“Тополя” Т.Шевченка» і т.д. Їх основні положення та ідеї дають ключ не лише для глибокого розуміння закономірностей формування та становлення народного світогляду, а й для з'ясування народних джерел національної самобутності української літератури, духовної культури українського народу загалом.

Аналіз актуальних досліджень. Поглядам І.Франка на народну творчість та іiі значення в розвитку національного письменства присвячено цілий ряд досліджень О.Дея [Дей 1955], Т.Рудої [Руда 1974], М.Нечиталюка [Нечиталюк 1970], Р.Кирчіва [Кирчів 1978], М.Дмитренка [Дмитренко 2004], Я.Гарасима [Гарасим 2009: 172-197] та інших вчених. У них йдеться, насамперед, про фольклористичну діяльність письменника і вченого, про вплив усної народної творчості на формування його світогляду, основоположних підстав народознавчих досліджень та творчого методу як художника слова. Однак питання народного світогляду, народної естетики, зокрема в науковому потрактуванні І.Франка, досі залишаються поза увагою франкознавців. Докладне ж, глибоке та усебічне їх вивчення відкриває нові можливості не лише для наукового пізнання джерел та особливостей світогляду українського на- 
роду, творчої особистості письменника, а й формування та становлення франківської школи в сучасному вітчизняному народознавстві та літературознавстві, питомо національного духовного світу та національної громадянської позиції нових поколінь українців, дієвого протистояння національному винародовленню в умовах навальної глобалізації усіх сфер нашого національного життя.

Наша мета полягає у з'ясуванні природи художньо-естетичного освоєння дійсності в українській усній народній поетичній творчості в процесі іiі формування, становлення та розвитку як розумів та потрактовував їх І.Франко, а завдання - у тому, щоб на основі аналізу народознавчої спадщини ученого окреслити питомо національні основоположні підстави дослідження ним цих проблем, їх значення для сучасних гуманітарних наук.

Виклад основного матеріалу. На основі усебічного аналізу народнопоетичних явищ I.Франко виокремив три шари народнопоетичного світогляду, які відповідають трьом періодам його формування, становлення і розвитку. Це - 1) прадавній, доміфологічний (фетишизм, анімізм), 2) новий, міфологічний (міфи) та 3) новітній, післяміфологічний (синкретизм народної психології, моралі, етики, естетики, філософії, соціології і т.д.). Спільною їх естетичною основою є емоційні (ще ширше - психічні) реакції на навколишній світ, його сприйняття і розуміння, які стають джерелом уяви, фантазії, визначають особливості ставлення людини до цього світу і свого місця в ньому. Однак на кожному етапі становлення народнопоетичної свідомості вони виявляються по різному.

Так, сутність прадавніх, доміфологічних, первісних емоційно-психологічних реакцій людини на світ, іiі уявлень про нього, первісного світовідчуття, світосприйняття, світорозуміння, світовираження і світоутвердження загалом визначає нерозривна єдність, повна злитість людини з природою. Людина у такому разі ще не виділяє себе з природи, вона живе в ній як природна її складова, уподібнює себе їй і їі собі. Відмінність же полягає в тому, що людина лише прагне пізнати, зрозуміти, пояснити природу в ціло- 
му, отже і себе в ній як іiі невід’ємну складову, намагається привести себе у повну відповідність з тим чи іншим її станом. Колективне начало у такому разі виявляється в однакових емоційних реакціях учасників того чи іншого дійства на світ, в однакових їх діях, отже й відсутності будь-яких ознак індивідуальності. У статті «Як виникають народні пісні» ці особливості народнопоетичного мислення І.Франко пояснює кількома обставинами. Це, по-перше, однаковий ступінь розумового розвитку, інтересів, прагнень і занять учасників творення пісні. По-друге, народний поет, зазначає автор статті, «творить свою пісню $з$ того емоційного та ідейного матеріалу, яким живе вся маса його земляків» [Франко 1980: 62], адже він не виокремлюється 3 маси як індивідуальність і не може 3 власної душі «зачерпнути ані іншого змісту, ані інших форм, крім тих, що становлять щоденне життя цілої маси» [Франко 1980: 62], відтак у його пісні знаходять своє відображення думки, враження та прагнення цілої маси. По-третє, відповідні колективні реакції на світ збуджують розум, викликають почуття, які переходять у дію (крики, рухи, стрибки, жести, звертання і т.д.). На основі такої неодноразової повторюваності та масовості й твориться пісня. «Кожне нове повторення подібного факту або явища, - підсумовує І.Франко, - викликає новий вибух спільного почуття, нову імпровізацію на давній мотив і одночасно нове збагачення, розвиток іiі тексту, підпорядкування його певному ритмові під такт спільного танцю і під акомпанемент спільних мімічних рухів» [Франко 1980: 63]. У процесі подальшого побутування такий твір зазнає постійних змін, удосконалюється його як зміст, так і форма.

Духовно-світоглядною основою народнопоетичної творчості у доміфологічний період є фетишизм та анімізм, в основі яких ідеалізація навколишнього світу, його обожнювання. І.Франко глибоко і усебічно з'ясовує їх естетичну природу. Насамперед, він зазначає, що людину і фетиш об'єднує таємнича сила, дух, демон, які шкодять чи то допомагають людині, що за відсутності свого життєвого досвіду людина сприймала речі, явища природи, навко- 
лишній світ загалом як відображення самої себе, наділяла їх властивостями, характерними їй самій, обожнювала їх. Саме ось цим одушевленням дерев, квітів, каменів, сонця, вітру і т.д., і т.п. пояснюється їх ідеалізація, залежність від них, намагання ублагати чи то задобрити їх. Цінність таких спостережень І.Франка полягає в тому, що він виокремлює дві складові в такому світогляді як єдине ціле, а саме - психологічне та етичне начала.

Психологічне начало виявляється в тому, що дух, який згідно уявлень первісної людини, ввібрали в себе явища природи i який стає їх суттю, вступає у взаємини з людиною. Своїми чуттями він відгукується на їі чуття, на іiі благання, дії і вчинки, викликаючи в собі такі само почуття і переживання. Етичний же момент засвідчує нерівномірне співвідношення сил, і тоді дух, втілений у фетиші, діє через нього, вливає на людину в тому чи іншому напрямку. Істотну роль відіграє тут і час: людина клопочеться не лише теперішнім своїм станом, а й піклується про своє майбутнє, намагається своїм звертанням до фетиша задобрити його i тим самим забезпечити собі бажане як тепер, так і в майбутньому. Та все ж таки первинним у такому разі є психологічне начало, яке й обумовлює естетичну настанову, дії і вчинки первісної людини, вказує на залежність ії від природи, пасивність перед іï силами.

Однак нерівномірність взаємозв'язків цих начал, нерівномірність сил криє в собі й перспективу розвитку саме етичного змісту цих взаємозв'язків і сил, що само собою веде до еволюції фетишизму. Змінюються також особливості психологічних уявлень про людину і світ. Впливаючи на різні сфери життя людини, насамперед на мову та мислення, фетишизм став одним $з$ першоджерел поетичного символу, метафори, інших поетикальних утворень в усній народній творчості та писемній літературі. У статті «Останки первісного світогляду в руських і польських загадках народних» І.Франко наводить такі вирази нашої мови, як «сонце сходить», «дощ іде», «ніч заскакує подорожнього», «вітер гуляє», «мороз тисне», «гори підносяться» і т.д. Їх природу він пояснює відгомоном 
саме фетишизму, адже в цих поетичних метафорах, хоча ми й сприймаємо їх як буденні явища сучасного мовлення, збереглися оті стародавні одушевлення навколишнього світу, уподібнення його людині. Не випадково на основі таких спостережень дослідник робить переконливий висновок: те, що колись «було релігією, то нині єсть поезією» [Франко 1980: 333].

Анімізм І.Франко потрактовує як новий, подальший крок у становленні естетики та поетики усної народної творчості. Найхарактернішою особливістю цього шару народного світогляду $\epsilon$ чітке розмежування речі, явища та їх суті. Душа в анімізмі як сутність речі чи явища нерідко залишає тіло, отже існує поза ним, стає іiі символом, діє, часом зовсім незалежно від волі людини, вона може переселятися в інше тіло, несучи при тому відповідну інформацію. Як приклад таких дій, такого переселення, такого символу вчений наводить мотив чудесного перетворення у казках, викриття вбивства брата чи сестри $з$ допомогою сопілки і т.д., і т.п. Саме ось таке чудесне виявлення страшного злочину, пише І.Франко у статті «Національний колорит у казках Бодянського», вказує на те, що ці та подібні народні уснопоетичні твори постали «не в лоні первісної, дикої суспільності, де ціна людського життя була невелика, а ненастанна боротьба між племенами робила смерть щоденним явищем» [Франко 1981: 450], а значно пізніше, «в лоні культурної суспільності, де людське життя було бережене грізними законами і де почуття страшного злочину в убивстві творило важну часть релігійного культу» [Франко 1981: 450]. Такий висновок підтверджується й аналізом загадок. Скажімо, у загадці «Прийшов хтось та й взяв щось, пішов би за ним, та не знаю за ким» І.Франко вбачає яскраво виражений критичний аналіз морально-етичних взаємин між людьми на якісно новому рівні їх розвитку, коли соціальне начало, а не залежність від природи, стало визначальним у формуванні цих взаємин. Разом з тим сліди анімістичного світосприйняття та світорозуміння тут цілком очевидні. Насамперед це виявляється в нечіткому, надто загальному 
окресленні душі отих «хтось», «щось», «не знаю за ким», що й характерне для стародавніх шарів народного світогляду. В суто ж естетичному плані такі спостереження І.Франка дають усі підстави говорити про усе активніші й активніші намагання людини пізнати світ і себе в ньому, про поступову диференціацію у ставленні до явищ повсякденної дійсності, та їх оцінки, що знаменувало перехід доміфологічних форм мислення у форми мислення міфологічного.

Питання походження міфу, його естетичної природи та міфопоетики - одна 3 найважливіших проблем, яку також розв'язував I. Франко як народознавець. Скажімо, з'ясовуючи під цим кутом зору життєві витоки різдвяної пісні, записаної 1885-го року священиком М.Зубрицьким у карпатському селі Мшанець, він доходить висновку, що 1) першоджерелом міфу є враження, викликані повсякденною реальною дійсністю, але в особливому поетичному світосприйнятті та світорозумінні і 2) особливістю цього світосприйняття та світорозуміння $є$ те, що той чи інший образ, мотив, поступово втрачаючи зв'язок 3 цією дійсністю, починали існувати самостійно, виконувати як і у міфі, функцію магічного священнодійства, ставали свого роду обрядом, ритуалом. До того ж, у процесі еволюції міфологічні мотиви, насамперед у народних загадках, набирали національного забарвлення як у змісті, так і у формі. На доказ цього він наводить українську народну загадку «Зоря-зоряниця, красная дівиця ключі погубила, сонце вкрала». Міфологічна основа загадки, продовжує свої спостереження дослідник, в ній цілком очевидна. Зоря-дівчина тут виступає як повновладна господарка землі, вона наділена незвичайними якостями, але ці якості грунтуються на основі національної психології, зокрема народнопоетичних уявлень про красу та фольклорних засобів іiі вираження, адже порівняння дівчини із зорею - один із найпоширеніших образів в українських народних піснях та казках. Таким чином, доходить висновку І.Франко, зберігаючи свою прадавню основу, міф усе ширше й ширше осмислює й відображає ті чи інші сфери, події, явища і т.д. національної історії, національне життя 
взагалі. Разом з тим він зазначає, що за всієї сили поетичної фантазії життєва основа тут проглядається зриміше, ніж на ранніх етапах становлення і розвитку міфологічного мислення, що, у свою чергу, засвідчує складний процес деміфологізації мислення і переходу до художньо-естетичного освоєння народної психології, моралі, етики, естетики, філософії, соціології і т.д.

Цей перехід - діалектичний. Відбувається не лише відмирання первісних уявлень про людину і світ, первісних форм мислення загалом, а й поява нових, як то язичництво, демонологія тощо, в їх тісних взаємозв'язках та взаємозумовленостях. Скажімо, естетичною природою творення образів богів у язичництві $є$ ріст особистісного начала, особистісного ставлення до них. Так, Сварог, Даждьбог, Перун, Мокоша, Дана, постають в народних уявленнях як людиноподібні істоти, як і люди вони діють самостійно, незалежно від людини. Це вже не ті фетиші, у яких душа і сам фетиш нероздільні, а фетиші, створені людською уявою, тобто образи, які стають предметом обожнювання та поклоніння. Зрозуміло, що рівень особистісного ставлення у цьому поклонінні виявляється ще досить невиразно, має більше колективний характер, але розмежування між творцями таких образів та самими образами тут уже цілком очевидні. Те само стосується й демонології.

Знову ж таки, повсякденна дійсність, викликані нею враження, почуття та переживання й тут стають першоджерелом поетичної творчості. Але спектр цих вражень, почуттів та переживань значно ширший і багатший у порівнянні з фетишизмом, анімізмом та міфом. Особистість у них заявляє про себе усе виразніше й виразніше, усе багатогранніше й багатогранніше, помножуються й можливості художньо-естетичного освоєння дійсності. Завдяки цьому в процесі такого освоєння відбувається синкретизм народної етики, естетики, психології, філософії, соціології, а нерідко й доміфологічних та міфологічних уявлень про людину і світ. Не другорядну роль тут відіграло й християнство. Коли, зазначає І.Франко у рецензії на працю Ю.Яворського «Духовный стих о 
грешной деве и легенда о нерожденных детях», у язичницві й знаходила своє відображення боротьба прямо протилежних сил, то це була боротьба сил світла і темряви. Відтак вона не мала етичного спрямування, етичного змісту. Цим учений пояснює перевагу світлих, радісних, життєстверджуючих мотивів та інтонацій, буяння життя, любові, світлих поривань в українських народних колядках, щедрівках, веснянках, пов'язаних з ними звичаях та обрядах, віру у магічну силу слова і спілкування 3 його допомогою 3 душами померлих. Введення ж нової релігії зумовило суттєві, протиприродні зміни у світогляді українського народу, адже «християнство не тільки не усунуло свого погляду, але противно, зміцнило його, вказуючи життя загробне яко прямий наслідок, кару або заплату за життя земнее» [Франко 1980: 79]. До того ж, давнім віруванням воно «надало темну, зловішу закраску» [Франко 1980: 79]. Відтак під впливом головно «аскетичних $i$ песимістичних сект маніхейських, давня віра в солідарність і симпатію між мертвими i живими перемінилася в віру упирів, котрі по смерті шкодять людям і всилуються погубити їх тіло і душу» [Франко 1980: 7980]. Усе це наклало свій відбиток на появу та ідейно-тематичне спрямування, естетику та поетику деяких жанрів усної народної творчості та писемної літератури, насамперед пісень християнського змісту та «житій святих». Однак такі впливи християнства не могли визначити і не визначили суті національної специфіки нашої усної народної поетичної творчості та нашого вітчизняної писемної літератури. Вони продовжували розвиватися своїм природним шляхом, на своїх природних національних підставах. Під впливом повсякденної дійсності, історичних обставин, цінностей національного духовного, соціального та культурного життя 3'являються нові теми, проблеми, ідеї, мотиви та образи, продовжують формуватися та утверджуватися питомо національні естетичні підстави появи нових жанрів у літературі та народній творчості, питомо національні поетикальні утворення. На національному грунті поглиблюється й етичне начало, увиразнюється естетичне відношення 
учасників уснопоетичного та літературного процесів до дійсності. Неабияке зацікавлення 3 цього погляду викликають «Студії над українськими народними піснями», розвідки «Українці», «Жіноча неволя в руських піснях народних», «Етнографічна експедиція на Бойківщину» та інші фольклористичні праці І.Франка.

Так, на основі аналізу соціально-побутових пісень про родинні взаємини вчений з'ясував діалектику еволюції поглядів українського народу на сім'ю та шлюб, художньо-естетичні особливості їх зображення в народній ліриці.

Першоджерелом творів цієї тематики та проблематики також є життя, але підстави його художньо-естетичного освоєння у них мають свої особливості, які й окреслюють їх як вияв вищого етапу, нового рівня народнопоетичної свідомості. Насамперед, І.Франко вказує на те, що на цьому етапі, на цьому рівні перед людиною відкриваються нові можливості здійснення свого внутрішнього «Я», нові можливості засвоєння досі незнаних явищ, тих чи інших сторін дійсності загалом. Однак ці нові можливості, хоча й зумовлені новою дійсністю, новим характером почуттів, вражень, емоційних реакцій на світ, новим світовідчуттям, світосприйняттям, світорозумінням, світовираженням та світоутвердженням в цілому, не постають самі по собі, а цілком природно вливаються у світогляд попередніх поколінь, розвивають, увиразнюють і збагачують його новими, насамперед соціальними мотивами, поглибленим психологічним аналізом явищ дійсності, новими поетичними формами.

Грунтовно та усебічно І.Франко 3'ясував діалектику нового i старого в народному уснопоетичному поступуванні на прикладі пісень про шандаря та вбивство Якимом своєї жінки. Кожен герой у них, доводить вчений, окреслений глибоко, чітко та яскраво. I Миколайчик, і Яким, і їх дружини справді-таки сповна реалізують своє внутрішнє «Я», що також засвідчує ріст особистісного начала в художньо-естетичному освоєнні дійсності творцями та виконавцями цих пісень. Разом з тим ці герої зображені у піснях крізь призму громадської думки, кожен їх крок, кожен вчинок, їх внутрішні 
почуття і переживання осмислюються крізь призму народної свідомості, потрактовуються, розуміються і оцінюються на підставах ідей та принципів народного гуманізму.

Так, оцінка пристрасної відданості заміжньої жінки своєму коханому, що виражається в осуді демонстративності їі поведінки, викликає, співчуття до неї, співпереживання їі моральної драми, що потрясла усе єство, змінила погляд героїні на людей і світ в цілому. Християнська мораль у такому разі у всьому нещасті звинувачувала б жінку. Та закінчення народної пісні, як підкреслює І.Франко, пояснює це зовсім по-іншому. Народ бачить засліпленість почуття героїні та при тому й виявляє розуміння того, що ця любов сильна, чиста, гаряча і невмируща. А така любов, підсумовує він, «єсть головним двигачем иілого життя $i$ поступування» [Франко 1980: 250], тому в народі вона знаходить не осуд, а співчуття.

Зовсім інше ставлення сільської громади до жандарма, оскільки він грає на щирих почуттях жінки і тим самим протиставляє себе не лише їй, а й усій громаді. Служба, влада, безкарність здеморалізували його, зробили безсердечним, черствим і зверхнім навіть у ставленні до своєї обраниці, призвели до повного відчуження від атмосфери народного життя, нехтування принципами народної моралі та етики. «Звичайний, простий парубок, - пише І.Франко, - хоч $і$ який, не зробив би чогось подібного» [Франко 1980: 252].

Прагненням зрозуміти слабосилість героїв пісні про вбивство Якимом своєї жінки пояснює І.Франко й співчуття до них. Народ не виправдовує ані Якима, ані його коханки, але й не має до них злоби, співчуває їм як людям, які піддавшись своїм почуттям, виявиши наївність і слабодухість, у своєму моральному падінні опустились до злочину. Отже, основне ідейне та повчальне спрямування пісні несе в собі не мотив кари, а співчуття безвільності безхарактерності та слабодухості як спосіб застереження від таких вчинків. Факт вбивства вже стався, Яким поніс заслужену кару, 
його заковують у кайдани і «йому прийдеться висидіти довгий час у слідчім арешті, а вкінщі або повиснути, або піти навіки гнити в тюрму» [Франко 1980: 237]. Та народна свідомість не задовольняється цим, адже кара, нехай і найжорстокіша, ще не усуває усіх можливостей повторення такого вчинку. А це не може не непокоїти громаду, тому їі співчуття слабодухості Якима і є виявом прагнення до кінця зрозуміти мотиви такого вчинку, навчати інших на його прикладі здатності переборювати в собі свої слабості , формувати таким чином сильні, вольові характери. «Муза народна глядить глибше і судить гуманніше, ніж учена справедливість» [Франко 1980: 237], - так визначає І.Франко сутність народного гуманізму.

Отже, на основі усебічного аналізу даних фольклору, етнографії, народної психології, моралі, етики та філософії вчений дав досить чітку концепцію еволюції народнопоетичних уявлень про Людину і світ на першому етапі післяміфологічного періоду їх становлення. Етап цей характеризується синтезом різних шарів народного світогляду з яскраво вираженою тенденцією до розвитку психіки, поглиблення чутливості як основи переходу від пояснення до пізнання людиною навколишнього світу, самої себе і явищ у ньому. За того світ цей постає не стільки у символах, скільки в поетизованих реаліях повсякденної дійсності, що подаються в глибоко психологічному освітленні.

3 історичним розвитком суспільства, із загостренням боротьби українського народу проти політичного, національного та соціального гніту виробляються й нові, відповідні цим явищам, форми народної самосвідомості, відбувається наповнення новим змістом старих уявлень про людину і світ.

Прикметною ознакою нової естетичної свідомості стала поява народного героїчного епосу, яку І.Франко пов’язує з довготривалою боротьбою українського народу проти турецько-татарських, польсько-шляхетських єврейських та московських поневолювачів, з ідеєю державної незалежності України. Скажімо, переростання 
мотиву боротьби за християнську віру 3 турецько-татарськими поневолювачами у мотив козацьких порядків, які необхідно налагоджувати на своїй землі («козакам козацькі порядки давати»), дослідник пояснює ростом національної свідомості широких народних мас українського народу, їх прагненням до державної самостійності.

На основі аналізу пісень та дум І.Франко показує, що структуру народної свідомості у такому разі визначають опозиції «соціальний, національний та духовний гніт - прагнення волі, свободи, усвідомлення національної честі та гідності», «поневолення - свобода», «панування чужинців на нашій землі - протест, повстання проти них». За того маємо іще одне яскраве свідчення високого рівня національно-державницької свідомості нашого народу, відображеного в думах та історичних піснях. Це, насамперед, зображення настроїв і сподівань українського народу, оповиті серпанком слави, всенародної любові і шани образи героїв національновизвольної боротьби проти чужоземних поневолювачів, які і є переконливим свідченням того, що визвольні змагання цих героїв, ідея незалежної української держави не лише співзвучні народним настроям, вони - сама суть народного світогляду, один з найяскравіших його проявів. Яскраве відображення ці настрої та сподівання, ці вияви любові і шани знайшли в думах про Хмельниччину, «Про жидівскі відкупи та про війну через них», цілому ряді історичних пісень. Скажімо, у думі «Про жидівські відкупи та про війну через них» йдеться про небачені здирства євреїв-орендарів, про безправність українського козацтва. Тоді, коли козак минає шинок, то його насильно заганяють туди аби зідрати з нього гроші. Утиски і здирства дійшли то того, що селянин навіть не має права вільно ловити рибу. Усе те викликало спротив у середовищі козаків та селян, і вони разом з Богданом Хмельницьким дали рішучу відповідь чужинцям-зайдам, та таку, що як говориться в одному 3 варіантів думи, самі євреї, втікаючи з України, 
Як узяли свого Рабина Мошку проклинати:

«Бодай ти, Мошку, щастя й долі не мав,

Як ти побагато на Вкраӥні одкупу брав!

А якби ти був, Мошку,

Та брав на Вкраїні одкупу потрошку,

То ми б на Вкраӥні проживали,

То нас би козаки українські

Вельможними панами називали!» [Франко 1986: 186].

Ці та подібні міркування І.Франко підтверджує також даними літописів та інших документів і показує таким чином, що народні соціологічні погляди на характер національних та економічних взаємин мають яскраво виражений не лише соціальний, а й морально-етичний зміст, що національна соціальна, економічна, моральна й духовна свобода для українських козаків та селян становить висхідний пункт взаємин у повсякденному житті, основу їх національного світогляду, їх національної громадянської та суспільно-політичної позиції. В цьому він вбачав благотворний вплив Хмельниччини на різні верстви і прошарки українського суспільства, тому й не випадково зауважував постійний і глибинний інтерес кобзарів до історії, старовини, до побуту, звичаїв запорожців, тобто до всього, що визначає суть і основи державності нації. Тому-то, зазначав І.Франко, в їх думах і піснях немає ні нудної солодкуватості, ні переніженого чуття, ні розкішних висловів, «в них усе дике, подібне до тих дібров, степів, що виховали їх та прийняли на своє лоно при вродженні, скрізь пориви, подібні до польоту степових вітрів, під котрих глухим завиванням вилеліяні вони все бурливе, як минуле життя Запорожжя» [Франко 1984: 486-487]. Само собою зрозуміло, що це визначило й національну самобутність поетичної системи тих дум та пісень.

Висновки. Дослідження І.Франком трьох етапів становлення народнопоетичної художньо-естетичної свідомості українського народу дало йому можливість з'ясувати природу та діалектику iii національної самобутності. На основі аналізу народнопоетичних 
уявлень українців та їх предків про людину і світ він дійшов переконливого висновку: на всіх - прадавньому (доміфологічному), новому (міфологічному) та новітньому (післяміфологічному) етапах джерелом та основою художньо-естетичного освоєння дійсності були емоційно-психологічні реакції людини на навколишній світ, викликані ними почуття, враження і переживання, прагнення пізнати, зрозуміти і пояснити цей світ. Але на різних етапах це виявилось по-різному. Для доміфологічних уявлень найхарактернішим було повне злиття людини з природою, повна залежність від неї та підпорядкованість їй. Основою ж світовідчуття, світорозуміння, світовираження та світоутвердження стало виокремлення людини $з$ природи, що відкрило нові можливості пізнання, розуміння та художнього зображення світу, зумовило ріст особистісного начала, яке у післяміфологічному мисленні синтезувало в собі історичний, соціальний, морально-етичний і т.д. зміст, поглиблюючи тим самим психологічний аналіз в процесі художньоестетичного освоєння та зображення тих чи інших подій і явищ повсякденного буття, зумовило появу нових жанрів та поетикальних утворень. Ідеї, положення та висновки народознавчих праць І.Франка становлять, таким чином, питомо національні основоположні підстави дослідження естетики та поетики української усної народної поетичної творчості, відкрили нові можливості з'ясування народних джерел національної самобутності писемної української літератури.

\section{БІБЛІОГРАФІЯ}

Гарасим 2009 - Гарасим Я. І. Нариси до історії української фольклористики.

Навчальний посібник. - К., 2009. - 301 с.

Дей 1955 - Дей Олексій. Іван Франко і народна творчість. - К., 1955. - 430 с. Дмитренко 2004 - Дмитренко Микола. Українська фольклористика другої поло-

вини XIX століття: школи, постаті, проблеми. - К., 2004. - 384 с.

Кирчів 1978 - Кирчів Р.Ф. Етнографічне дослідження Бойківщини. - К., 1978. - 358 с. Нечиталюк 1970 - Нечиталюк М.Ф. 3 народних ручаїв. - Л., 1970. - 168 с.

Руда 1974 - Руда Т.П. Іван Франко - дослідник слов'янського фольклору. - К., 1974. $-184 \mathrm{c}$.

Франко 1980 - Франко І. Жіноча неволя в руських піснях народних // Франко

Іван. Зібр. творів: У 50-и т. - К., 1980. - Т. 26. - 463 с. (с. 210 - 253). 
Франко 1980 - Франко І. Останки первісного світогляду в руських і польських загадках народних. // Франко Іван. Зібр. творів: У 50-и т. - К., 1980. - Т. 26. (c. 332-344).

Франко 1980 - Франко І. Як виникають народні пісні. // Франко Іван. Зібр. творів: У 50 -и т. - К., 1980. - Т. 27. - 464 с. (с. 57 - 65).

Франко 1980 - Франко I. 'Тополя”' Т.Шевченка. // Франко Іван. Зібр. творів: У 50-и т. - К., - Т. 28. -440 с. (c. $73-88)$.

Франко 1981 - Франко I. Національний колорит у казках Бодянського. // Франко Іван. Зібр. творів: У 50-и т. - К., 1981. - Т. 34. - 560 с. (с. $449-454)$.

Франко 1984 - Франко І. Студії над українськими народними піснями. Пісні й дума про Серп'ягу (Івана Підкову) (1578). // Франко Іван. Зібр. творів: У 50-и т. - K., - T. $42 .-599$ c. $($ c. $475-489)$.

Франко 1986 - Франко І. Студії над українськими народними піснями. Хмельниччина (думи, пісні та вірші). // Франко Іван. Зібр. творів: У 50-и т. - Т. 43. 483 c. (c. 7-193).

Стаття надійшла 2 вересня 2013 p. 